\title{
PENGOPERASIAN MESIN PENDINGIN UNTUK COLD STORAGE PENYIMPANAN IKAN BEKU DI PT. DWI BINA UTAMA SORONG
}

\section{OPERATIONAL OF REFRIGERATION MACHINE FOR COLD STORAGE AS FROZEN FISH HOLD IN PT. DWI BINA UTAMA SORONG}

\author{
Djoko Prasetyo ${ }^{1}$, Muhammad Zaki Latif Abrori ${ }^{1}$, Andreas Pujianto ${ }^{1}$ \\ ${ }^{1}$ Politeknik Kelautan dan Perikanan Sorong \\ JI. K. Pattimura, Tanjung Kasuari, Sorong, Papua Barat
}

Email: djokoprasetyo19@gmail.com,m.zaki@kkp.go.id, andnika.AP@gmail.com

\begin{abstract}
ABSTRAK
Ikan merupakan salah satu sumber protein yang baik bagi manusia, hanya saja daging ikan tersebut mudah menurun kualitasnya, untuk mempertahankan kualitas daging ikan perlu di dinginkan. Salah satu alat yang di gunakan untuk mendinginkan ikan adalah menggunakan mesin pendingin. Mesin pendingin merupakan mesin yang kompleks, terdiri dari beberapa komponen dan dalam pengoperasinya harus tepat, kekeliruan dalam pengoperasian akan mengakibatkan kegagalan operasional mesin yang berdampak pada kerugian. Tujuan penelitian ini adalah untuk mengetahui sistem mesin pendingin pada cold storage, mengetahui komponen mesin pendingin pada cold storage dan mengetahui pengoperasian mesin pendingin pada cold storage. Metode yang digunakan adalah studi kasus mengenai pengoperasian mesin pendingin, Hasil penelitian kemudian di paparkan secara deskriptif. Mesin pendingin yang digunakan menggunakan sistem kompresi uap, komponen yang digunakan adalah kompresor, kondensor, katup ekspansi dan evaporator. Untuk mengoperasikan mesin sebelumnya memastikan mesin dalam kondisi baik dan aman untuk dioperasikan, selanjutnya memastikan tegangan sebesar $380 \mathrm{~V}$ dan katup dalam kondisi terbuka agar refrigeran dapat bersirkulasi. Mesin bekerja secara otomatis dengan di pandu komponen kontrol untuk mendapatkan tekanan hisap 19 Psig, tekanan dorong sebesar 230 Psig. Mesin ini menggunakan alat pengaman HPC, LPC, OPC, dan thermal overload untuk mencegah dari kerusakan. Pengoperasian mesin telah dilaksanakan sesuai dengan petunjuk teknis dari pembuat mesin sehingga pengoperasian berjalan dengan lancar, temperatur ruang cold storage sesuai dengan nilai setpoint, dan produk yang disimpan didalam cold storage tidak terjadi penurunan kualitas.
\end{abstract}

Kata Kunci : pengoperasian, mesin pendingin, cold storage.

\begin{abstract}
Fish is a good source of protein for humans. It's just that fish meat is easy to degrade to maintain its quality that needs to be refrigerated. One of the tools used was a refrigeration machine. A refrigeration machine is a complex machine consisting of several components, and the operation must be precise. The mistake operation will result in machine operational failure, which has an impact on losses. This study aims to determine the system used, know the components, and know the cooling machine's know-how in cold storage. The method used is a study of the operation of the refrigeration machine. The results of the research are then presented descriptively. The refrigeration machine used uses a vapor compression system. The components used are compressor, condenser, expansion valve, and evaporator. To operate the machine before making sure the machine is in good condition and safe to operate, then make sure the voltage is $380 \mathrm{~V}$ and the inner valve is open so that the refrigerant can circulate. The machine will work automatically with the guidance of the control components to get a suction pressure of 19 Psig, a thrust pressure of 230 Psig. This machine uses HPC, LPC, OPC, and thermal overload safety devices to prevent failure. The operation of the machine has been carried out by the technical instructions from the machine maker so that the operation runs smoothly, The temperature of the cold storage room by the setpoint value, and the product stored in cold storage does not decrease in quality.
\end{abstract}

Keywords: operational, refrigeration machine, cold storage 


\section{PENDAHULUAN}

Salah Satu hasil laut yang banyak di manfaatkan di Indonesia adalah ikan. Mengoptimalkan hasil laut dengan cara mengolah hasil laut dengan baik. Perusahaan-perusahaan yang bergerak di bidang pengolahan hasil perikanan mempunyai peranan penting dalam menyediakan ikan sebagai konsumsi bagi masyarakat. Ikan banyak mengandung protein yang mudah rusak oleh pertumbuhan bakteri, sehingga untuk menjaga kualitas ikan, pertumbuhan bakteri dapat dihambat dengan proses pendinginan (Arjadi et al., 2018). Untuk mendinginkan pada proses pengolahan ikan hampir semua perusahaan menggunakan mesin pendingin mekanik. (Murtono et al., 2016). Penggunaan mesin pendingin mekanik pada industri perikanan dianggap paling efisien dalam proses penurunan suhu produk apabila di bandingkan dengan metode lain, oleh karena itu keberadaan mesin pendingin sangat dibutuhkan untuk mempertahankan mutu ikan (Priharanto et al., 2017)

Cold storage merupakan suatu alat yang terdiri dari bangunan dan mesin pendingin yang menampung benda-benda yang akan mengalami proses pendinginan. Unit cold storage biasa digunakan dalam kehidupan sehari-hari untuk mendinginkan atau mengawetkan makanan seperti daging, sayuran dan buah-buahan begitu juga dengan minuman (Świeca et al., 2018). Untuk dapat menyerap kalor pada produk (ikan) mesin pendingin menggunakan beberapa komponen yang di rangkai untuk dapat bekerja mendinginkan produk (Rasta et al., 2018). Beberapa komponen tersebut merupakan komponen kritis atau komponen utama karena apabila komponen tersebut mengalami gagal operasi, maka dapat mengakibatkan gagalnya operasional mesin (Priharanto et al., 2017). Komponen pokok tersebut diantaranya kompresor, kondensor, katup ekspansi dan evaporator (Mardiyono \& Fadillah, 2020).

Untuk mencegah kegagalan operasional mesin maka operator harus mengetahui bagaimana cara mengoperasikan mesin dengan baik. Untuk mendapatkan bagaimana cara mengoperasikan yang baik maka diperlukan prosedur pengoperasian yang mudah dipahami dan dilaksanakan oleh operator mesin. Operasional mesin yang dilaksanakan dengan baik maka akan berdampak operasional mesin yang optimal, prediksi usia pakai mesin sesuai dan mencegah terjadinya kegagalan prematur akibat kesalahan operasional. Adapun tujuan dalam pelaksanaan penelitian ini adalah untuk mengetahui sistem mesin pendingin pada cold storage, Mengetahui komponen mesin pendingin pada cold storage Mengetahui cara pengoperasian mesin pendingin pada cold storage.

\section{BAHAN DAN METODE}

Studi ini meneliti pada mesin pendingin untuk cold storage milik PT. Dwi Bina Utama Sorong. Cold strorage ini digunakan untuk menyimpan produk olahan perikanan yang sudah di bekukan sebelumnya oleh mesin freezer. Metode yang digunakan adalah studi kasus tentang bagaimana mulai persiapan mengoperasikan mesin dan pemantauan operasional hingga menghentikan operasional mesin.

Data di ambil dengan cara mencatat dan mengamati bagaimana sistem kerja yang digunakan pada mesin pendingin, dan bagaimana mengoperasikan mesin yang kemudian di bandingkan dengan prosedur pengoperasian mesin. Untuk mendapatkan bagaimana mengoperasikan mesin, diperlukan tahapan sebelumnya dengan cara; 1) Untuk mengetahui sistem refrigerasi pada unit cold storage dibuat skema dan dijelaskan sistem aliran refrigerannya kemudian di bandingkan dengan literatur dari jurnal yang sesuai; 2) Untuk mengetahui komponen sistem refrigerasi unit cold storage dijelaskan mengenai komponen utama, bantu, dan kontrol dengan penjelasan fungsi serta spesifikasinya yang terinstal; 3) Untuk mengetahui cara pengoperasian sistem refrigerasi pada unit cold storage dijelaskan cara pengoperasian teknisi di lapangan kemudian dibandingkan dengan instruksi kerja atau 
Buletin JSJ, 3 (1), 2021, 19-27

Available online di: http://ejournal-balitbang.kkp.go.id/index.php/JSJ/index

standar operasi prosedur dari perusahaan. Penjelasan pengoperasian ini dilengkapi dengan parameter tekanan, temperatur, tegangan, dan arus listrik selama unit cold storage beroperasi. Gangguan selama operasional dan tahapan penyelesaian masalah dipaparkan pada tabel.

\section{HASIL DAN PEMBAHASAN}

PT. Dwi Bina Utama merupakan salah satu perusahaan yang berlokasi di Jalan Bubara DS. Klaligi Sorong-98414 yang bergerak di bidang pengolahan hasil perikanan. PT. Dwi Bina Utama didirikan pada tanggal 12 September 1974 memiliki surat izin berusaha 9120201772324 diterbitkan pada tanggal 22 Juli 2019. Dalam pemasaran produk olahan udang perusahaan mengekspor ke beberapa negara di Asia yaitu Jepang, Vietnam, dan Taiwan. Perusahaan ini memiliki tenaga kerja sebanyak 82 orang. Perusahaan juga memiliki sarana di laut berupa kapal sebanyak 12 unit, dan sarana di darat berupa gedung kantor, bengkel, kantin, pabrik, gedung spare part, gudang fishing gear, mes karyawan, mobil dan sepeda motor.

Sistem pendingin pada unit cold storage penyimpanan beku milik PT. Dwi Bina Utama menggunakan sistem refigerasi mekanik dengan siklus kompresi uap, hal ini seperti pendapat Ambarita et al., (2018) yang mengatakan bahwa refrigerasi mekanik merupakan yaitu mesin pendingin yang menyirkulasikan bahan pendinginnya menggunakan mesin mekanik. Adapun sistem yang digunakan ditampilkan pada Gambar 1. Dengan spesifikasi ruangan cold storage di tampilkan pada Tabel 1.

Tabel 1. Spesifikasi mesin

\begin{tabular}{ll}
\hline Spesifikasi & \\
\hline Panjang & 12 meter \\
Lebar & 8 meter \\
Tinggi & 4 meter \\
Bahan & Polyurethane \\
Ketebalan & $10 \mathrm{~cm}$ \\
Lantai & Lantai semen dengan alas palet \\
Daya tampung & 80 ton \\
\hline
\end{tabular}

Sistem refrigerasi bekerja di mulai dari kompresor yang menyalurkan dan mengompresi uap refrigeran 404A (tekanan dan temperatur rendah) menjadi uap refrigeran bertekanan dan bertemperatur tinggi. Sebelum disalurkan ke kondensor, uap refrigeran masuk ke dalam oil separator untuk memisahkan refrigeran dan pelumas yang mengalir. Pelumas yang terakumulasi pada separator dikembalikan ke kompresor melalui saluran balik dengan membuka katup balik. 


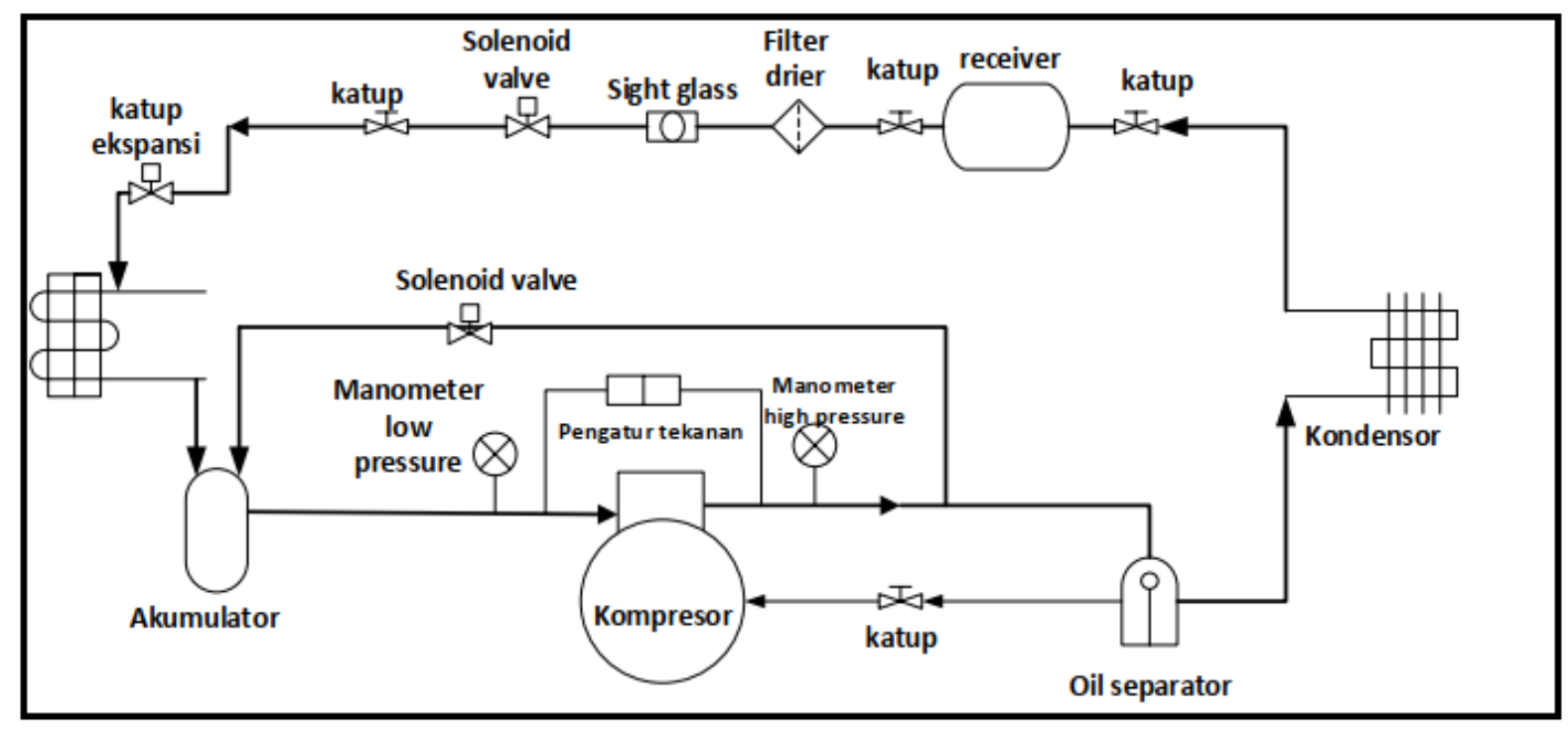

Gambar 1. Sistem refrigerasi cold storage

Di dalam pipa kondensor, refrigeran gas mengalami kondensasi sehingga refrigeran gas berubah wujud menjadi refrigeran cair, hal ini sesuai seperti yang di tuliskan oleh Siagian, (2017) pada artikelnya mengatakan bahwa kondensor berfungsi untuk membuang kalor dan mengubah wujud bahan pendingin dari gas menjadi cair. Hal ini terjadi karena adanya perbedaan temperatur refrigeran dengan air pendingin. Sebagai penampung, tabung receiver menampung sementara refrigeran cair sebelum di salurkan ke katup ekspansi hal ini sesuai yang dituliskan oleh Riyadi et al., (2016) dalam artikelnya yang menyatakan bahwa receiver digunakan untuk menampung refrigeran cair. Komponen filter drier dipasang pada saluran antara receiver dan katup ekspansi yang bertujuan untuk menyaring kotoran dan menyerap kandungan air yang ikut mengalir bersama refrigeran cair, dipasangnya filter and dryer ini sesuai yang dikatakan Hidayat \& Restu, (2017) bahwa filter and dryer menyaring dan menyerap kelembapan pada refrigeran. Sight glass dipasang untuk memeriksa aliran refrigeran apakah berbentuk cair atau terdapat uap refrigeran yang ikut mengalir. Jika terindikasi aliran refrigeran berbentuk gas, perlu adanya pemeriksaan ataupun penggantian pada filter drier, selain itu melalui sight glass juga dapat melihat kondisi kelembaban refrigeran. Katup solenoid juga terpasang pada saluran sebelum katup ekspansi. Katup ini akan menutup jika mesin dalam kondisi tidak beroperasi sehingga tidak ada refrigran yang mengalir menuju ekspansi dan evaporator.

Sebelum refrigeran mengalir ke evaporator terlebih dahulu akan diproses ekspansi, tekanan refrigeran akan diturunkan oleh katup ekspansi, hal ini sesuai dengan yang di sampaikan oleh Kusnandar et al., (2018) dalam artikelnya mengatakan katup ekspansi digunakan untuk menurunkan tekanan. Pada katup ekspansi, refrigeran cair bertekanan mengalami jatuh tekan dengan wujud spray. Karena tekanan di dalam pipa evaporator yang rendah, maka dengan suhu ruang cold storage refrigeran bentuk spray dengan mudah menguap menjadi wujud gas. Proses penguapan tersebut refrigeran menyerap kalor sehingga temperatur udara di evaporator menjadi rendah hal ini sesuai dengan yang disampaikan Hermawan \& Novianto, (2017) dalam artikelnya dituliskan bahwa pada tekanan yang rendah di dalam evaporator refrigeran menguap dan menyerap panas di sekitarnya. Temperatur udara yang rendah pada evaporator di sirkulasikan menggunakan kipas yang menghembuskan udara ke produk. 
Refrigeran wujud refrigeran bentuk spray diharapkan seluruhnya menguap dan berubah menjadi wujud gas untuk dapat di hisap oleh kompresor. Oleh karena itu mesin ini di lengkapi dengan suction accumulator, komponen ini memisahkan refrigeran spray dengan refrigeran yang belum menguap. Refrigeran yang belum menguap ditampung di dalam akumulator, sedangkan refrigeran uap di hisap oleh kompresor. Hal ini agar tidak terjadi liquid back yang dapat mengakibatkan kerusakan pada bagian dalam kompresor. Accumulator yang digunakan dapat meningkatkan kapasitas refrigerasi dengan memastikan refrigeran dalam kondisi superheated, fungsi accumulator ini sependapat dengan Arsana et al., (2018) dalam artikelnya dituliskan superheat dapat meningkatkan kapasitas dan COP mesin.

Sistem pendinginan ini dilengkapi alat kontrol berupa manometer untuk mengukur tekanan. Kontrol HPC (High Pressure Control) dan LPC (Low Pressure Control) digunakan pada saluran tekan dan hisap dekat kompresor. Komponen kontrol ini selain berfungsi sebagai pengatur tekanan kerja kompresor juga berfungsi sebagai pengaman, Hal ini sesuai dengan yang disampaikan oleh Isyanto \& Hidayat, (2017) HPC dan LPC digunakan untuk motor kompresor dengan parameter tekanan dan temperatur.

Berdasarkan Gambar 1. ada beberapa komponen mesin pendingin pada cold storage yang terdapat di perusahaan PT. Dwi Bina Utama, yaitu komponen pokok dan komponen tambahan. Komponen pokok yaitu kompresor, kondensor, katup ekspansi dan evaporator. $\mathrm{Hal}$ ini sesuai dengan yang tuliskan oleh beberapa penulis sebelumnya yang menggunakan mesin pendingin menggunakan beberapa komponen yang ditampilkan pada Tabel 2.

Tabel 2. komponen yang digunakan pada mesin pendingin

\begin{tabular}{lll}
\hline \multicolumn{1}{c}{ Penulis } & Komponen mesin pendingin & \multicolumn{1}{c}{ Mesin pendingin } \\
\hline Susilo et al., 2020 & Kompresor, kondensor, & Mesin dehumidifier untuk ekstraksi \\
& ekspansi, evaporator & vitamin A \\
Nasution et al., 2019 & Kompresor, kondensor, katup & Penyejuk udara menggunakan \\
& ekspansi, evaporator & refrigeran R290 \\
Hendradinata \& Mahendra, & Kompresor, kondensor, katup & Mesin pendingin udara ruangan \\
2016 & ekspansi, evaporator & menggunakan refrigeran R134a \\
Priharanto et al., 2017 & Kompresor, kondensor, katup & Mesin pendingin penanganan ikan \\
& ekspansi, evaporator & pada kapal penangkap ikan \\
Meilani, 2018 & Kompresor, kondensor, & Mesin chiller untuk industri \\
& ekspansi, evaporator & pengolahan minyak sawit \\
\hline
\end{tabular}

Kompresor pada PT. Dwi Bina Utama berjumlah 2 unit, berwarna hijau terletak pada bagian tengah mesin pendingin di antara oil separator dan akumulator, mesin yang digunakan dalam perusahaan yaitu type 4PES-12Y-40P (Bitzer Khulmaschinenbau gmbh), Adapun jenis kompresornya yaitu menggunakan jenis torak yang memiliki 4 silinder dan menggunakan tipe silinder vertikal. Berdasarkan motor penggeraknya yang digunakan pada kompresor yaitu menggunakan semi hermetis, dimana motor penggeraknya berada dalam satu bodi, untuk penggunaan listrik yang di gunakan yaitu 3 Phasa dan tegangannya $380 \mathrm{~V}$. Masing-masing kompresor memiliki merek dan fungsi yang sama yaitu mengompresi uap refrigeran dari evaporator sehingga tekanan dan temperaturnya menjadi lebih tinggi sebelum disalurkan ke kondensor.

Kondensor pada PT. Dwi Bina Utama menggunakan tipe fin and tube berpendingin udara yang di hembuskan menggunakan 2 unit kipas yang digerakkan oleh motor listrik. Cold storage ini menggunakan kondensor sebanyak 2 unit, berwarna hitam berbentuk persegi empat, terletak pada bagian atas pintu masuk ruangan mesin. Kondensor tersebut buatan 
Gunter dengan tipe G 50 2- N, tekanan maksimum 32 bar, suhu minimum/maximal yang diizinkan $+100 \mathrm{C} /-55 \mathrm{C}$.

Katup ekspansi yang digunakan adalah jenis thermostatic expansion valve berjumlah 2 unit, terletak di samping evaporator tepatnya sebelum pipa evaporator. Katup ekspansi ini digunakan untuk menurunkan tekanan refrigeran cair sehingga tekanan dan temperatur refrigeran menjadi lebih rendah daripada tekanan di reciver. Katup. Besarnya pembukaan katup secara otomatis diatur berdasarkan sensor temperatur yang dipasang pada evaporator

Evaporator pada PT. Dwi Bina Utama berjumlah 2 unit, terletak di bagian atas dalam ruangan cold storage, berwarna putih, masing-masing mempunyai 2 unit kipas, Evaporator ini menggunakan jenis fin and tube dan untuk pendinginnya dilakukan secara konveksi paksa dengan menggunakan 2 unit blower untuk menyirkulasikan udara dingin

Pengoperasian mesin pendingin

Pada saat melakukan pengoperasian sistem refrigerasi ada beberapa langkah tahapan yang harus yaitu persiapan, mengoperasian dan menghentikan operasional mesin.

Tahap persiapan. Sebelum mesin dioperasikan, pastikan keamanan kerja, baik bagi pekerja atau mesin, tidak ada komponen mesin yang sedang dalam perbaikan atau tidak ada pekerja yang sedang melakukan perawatan atau perbaikan bagian mesin. Selanjutnya memastikan tegangan listrik pada panel kontrol sebesar 380 - 400 volt, apabila tegangan listrik tidak pada rentang tersebut, mesin tidak di anjurkan untuk beroperasi karena dapat merusak komponen kelistrikan. Tahap berikutnya nyalakan heater pelumas kompresor, lampu ruangan depan cold storage, lampu lorong cold sorage. Selanjutnya membuka semua keran manual yang menghubungkan komponen kompresor, kondensor, receiver dan evaporator agar refrigeran dapat bersirkulasi di dalam sistem.

Tahap pengoperasian. Mesin cold storage milik PT.DBU sudah cukup modern dapat bekerja dengan sistem otomatis. Untuk mengoperasikan mesin pendingin pada cold storage tindakan yang dilakukan adalah menekan tombol ON pada panel kontrol, dengan menekan tombol ON, maka mesin beroperasi secara otomatis yang dipandu dengan komponen kontrol seperti HPC, LPC. Mesin akan beroperasi apabila tekanan dan temperatur set point belum tercapai, dan akan berhenti apabila temperatur sudah tercapai. Mesin pendingin ini juga di lengkapi dengan alat pengaman seperti HPC, OPC, thermal overload, hingga fuse breaker yang akan menghentikan operasional mesin secara otomatis apabila ada anomali pada parameter yang ditentukan.

Dalam pengoperasian mesin pengawasan oleh operator dan teknisi tidak boleh terlewatkan. Selama mesin beroperasi, operator dan teknisi tetap siaga memantau operasional mesin dengan tegangan antara $370 \mathrm{~V}-400 \mathrm{~V}$, arus listrik operasional motor listrik penggerak kompresor antara 4A - 5.5A, tekanan hisap 15-25 Psig dan tekanan discharge Apabila terdengar suara dan merasakan getaran yang tidak sesuai teknisi akan melakukan tindakan yang diperlukan. Termasuk memeriksa evaporator dari tumpukan bunga es dan membersihkan apabila diperlukan. Setiap dua jam dilakukan pencatatan parameter operasional mesin yang dicatat dalam buku catatan harian operasional mesin (engine log book), adapun data catatan harian tersebut di tampilkan pada Tabel 3. Tujuannya dilakukan pencatatan buku jurnal adalah sebagai bahan untuk menganalisis kinerja mesin dan membuat perencanaan perawatan dan perbaikan mesin, seperti penelitian dilakukan oleh Faisal \& Nugroho, (2016) yang menggunakan jurnal log book operasional mesin untuk menganalisis sistem pendingin pada generator listrik kapal. Kondisi pengoperasian mesin pendingin telah memenuhi standar SNI 4110:2014 tenang ikan beku dimana suhu pusat maksimal pada temperatur $-18^{\circ} \mathrm{C}$. Tingginya temperatur pada bagian suction hingga $-16^{\circ} \mathrm{C}$ 
Buletin JSJ, 3 (1), 2021, 19-27

Available online di: http://ejournal-balitbang.kkp.go.id/index.php/JSJ/index

dan $-17^{\circ} \mathrm{C}$ pada Tabel 3, No.1 dan 7 , hal ini terjadi karena evaporator baru dioperasikan setelah selesai dilakukannya perawatan rutin.

Tabel 3. Jurnal operasional mesin pendingin

\begin{tabular}{cccccc}
\hline No & $\begin{array}{c}\text { Tekanan kompresor (Psig) } \\
\text { hisap }\end{array}$ & $\begin{array}{c}\text { Arus } \\
\text { tekan }\end{array}$ & $\begin{array}{c}\text { Tegangan } \\
\text { listrik }(\boldsymbol{A})\end{array}$ & $\begin{array}{c}\text { Temperatur } \\
\text { suction }\end{array}$ \\
\hline 1 & 21 & 215 & 4,8 & 283 & $-16,6$ \\
2 & 16,67 & 230 & 4,5 & 393 & $-23,4$ \\
3 & 21 & 230 & 4,4 & 396 & $-23,6$ \\
4 & 21 & 226 & 4,8 & 395 & $-23,7$ \\
5 & 19,33 & 225 & 4,8 & 396 & $-24,1$ \\
6 & 18,5 & 225 & 4,8 & 397 & $-23,0$ \\
7 & 19 & 233 & 5,9 & 397 & $-17,4$ \\
8 & 18,75 & 232 & 4,9 & 396 & $-22,7$ \\
9 & 20 & 232 & 4,7 & 395 & $-23,7$ \\
10 & 20 & 231 & 4,5 & 397 & $-23,9$ \\
\hline
\end{tabular}

Tahap menghentikan. Pada PT Dwi Bina Utama, mesin pendingin untuk cold storage sangat jarang dihentikan operasionalnya, hal ini di sebabkan adanya beban produk udang di dalam cold storage yang tidak pernah kosong. Dihentikannya operasional mesin disebabkan karena hal yang penting, misalnya dilakukannya tindakan perawatan mesin. Untuk menghentikan operasional mesin, hal yang dilakukan adalah cukup menekan tombol OFF pada panel operasional mesin dan menutup keran saluran hisap pada kompresor.

\section{KESIMPULAN DAN SARAN}

Berdasarkan uraian hasil dan pembahasan di atas, penulis dapat menarik kesimpulan sebagai berikut; Sistem pendingin pada unit cold storage penyimpanan udang milik PT. Dwi Bina Utama menggunakan sistem pendingin mekanik siklus kompresi uap. Cold storage ini menggunakan unit mesin pendingin dengan kapasitas kompresor $12 \mathrm{PK}$ single stage, menggunakan refrigeran $\mathrm{R} 404 \mathrm{~A}$ dengan temperatur evaporator $-24.7{ }^{\circ} \mathrm{C}$. Komponen mesin pendingin terdiri dari komponen utama berupa kompresor, kondensor, katup ekspansi, dan evaporator. Komponen bantu berupa oil separator, receiver, filter drier, accumulator. Komponen kontrol berupa manometer, termostat, termometer, solenoid valve, sight glass, katup manual. Mesin pendingin pada cold storage dioperasikan secara otomatis dan pengoperasiannya yaitu memastikan tegangan sebesar 380 volt, tekanan freon sisi suction sebesar 60 psi, Pastikan MCB heather oli, lampu ruangan, lampu lorong, dalam panel listrik pada posisi ON dan tekan tombol kompresor pada posisi ON. Catat waktu operasi, tekanan hisap, tekanan discharge, arus motor listrik, tegangan, temperatur cold storage setiap dua jam pada jurnal jaga mesin. 
Buletin JSJ, 3 (1), 2021, 19-27

Available online di: http://ejournal-balitbang.kkp.go.id/index.php/JSJ/index

\section{DAFTAR PUSTAKA}

Ambarita, H., Halim Nasution, A., Ginting, S., \& Sihombing, H. V. (2018). The optimum temperature of single-stages vapor compression refrigeration cycle for Air-Conditioning unit. IOP Conference Series: Materials Science and Engineering, 420(1), 012038. https://doi.org/10.1088/1757-899X/420/1/012038

Arjadi, L., Nuryantoro, N., \& Harjanti, D. W. (2018). Evaluasi Cemaran Bakteri Susu Yang Ditinjau Melalui Rantai Distribusi Susu Dari Peternak Hingga KUD Di Kabupaten Boyolali. Mediagro, 13(1).

Arsana, M. E., Kusuma, I. G. N. W., Sucipta, M., \& Suamir, I. N. (2018). Comparative Analysis of Performance between Two Phase Ejector with Accomulator and COS Split Air-Conditioning Dual Evaporator. International Conference on Science and Technology (ICST 2018), 974-978.

Faisal, A., \& Nugroho, T. F. (2016). Technical Analysis of Organic Rankine Cycle System Using Low-Temperature Source to Generate Electricity in Ship. Jurnal Teknik ITS, 5(2), B394-B399. https://doi.org/10.12962/j23373539.v5i2.19309

Hendradinata, H., \& Mahendra, M. (2016). Analisa Pengaruh Resirkulasi Udara Pada Kabin Evaporator Terhadap Performansi Mesin Refrigerasi Kompresi Uap Air Conditioner Dengan Refrigeran R134a. Petra: Jurnal Teknologi Pendingin Dan Tata Udara, 2(1), 58.

Hermawan, S., \& Novianto, R. (2017). Trouble Shooting Sistem Air Conditioner (AC) PADA Trainer AC Mobil. Surya Teknika: Jurnal IImiah Teknik Mesin, 1(1), 26-33.

Hidayat, T., \& Restu, F. R. (2017). Pengembangan Desain Sistem Pengkondisian Udara Kereta Api Oleh PT. INKA (Persero). Jurnal Penelitian Transportasi Darat, 19(1), 13-36.

Isyanto, H., \& Hidayat, D. (2017). Monitoring Sistem Refrigerasi Pada Cold Storage Berbasis Scada. Prosiding Semnastek.

Kusnandar, K., Kurniawan, Y., \& Rohmat, Y. N. (2018). Analisa Performansi Mesin Pengkondisi Udara Menggunakan Refrijeran R-32. Proceedings Of National Colloquium Research And Community Service, 2.

Mardiyono, M., \& Fadillah, H. (2020). Perhitungan Beban Refrigerasi Terhadap Hasil Tangkapan Pada Km. Harapan Sri Jaya Juwana, Pati, Jawa Tengah. Jurnal Rekayasa Mesin, 15(3), 171-175.

Meilani, H. I. (2018). Identifikasi Bahaya Chiller Di Industri Pengolahan Sawit Menggunakan Metode Hazop Dan CCA. Jurnal Safety Engineering and Its Application, 1(1), 28.

Murtono, A., Kalangi, P. N. I., \& Kaparang, F. E. (2016). Analisis beban pendingin cold storage PT. Sari Tuna Makmur Aertembaga Bitung, Sulawesi Utara. Jurnal IImu Dan Teknologi Perikanan Tangkap, 2(2).

Nasution, D. M., Idris, M., \& Pambudi, N. A. (2019). Room air conditioning performance using liquid-suction heat exchanger retrofitted with R290. Case Studies in Thermal Engineering, 13, 100350. 
Buletin JSJ, 3 (1), 2021, 19-27

Available online di: http://ejournal-balitbang.kkp.go.id/index.php/JSJ/index

Priharanto, Y. E., Abrori, M. Z. L., \& HS, R. S. (2017). Penilaian Risiko pada Mesin Pendingin di Kapal Penangkap Ikan Dengan Pendekatan FMEA. Jurnal Airaha, 6(1), 24-32. http://www.jurnalairaha.org/index.php/airaha/article/view/86

Rasta, I. M., Susila, I. D. M., \& Subagia, I. W. A. (2018). Technology Application of Environmental Friendly Refrigeration (Green Refrigeration) on Cold Storage for Fishery Industry. Journal of Physics: Conference Series, 953(1), 12077.

Riyadi, M., Budiarto, U., \& Santosa, A. W. B. (2016). Analisa Teknis dan Ekonomis Penggunaan Sistem Pendingin Refrigerated Sea Water (RSW) Pada Kapal Ikan Tradisional. Jurnal Teknik Perkapalan, 4(1).

Siagian, S. (2017). Analisis Karakteristik Unjuk Kerja Kondensor Pada Sistem Pendingin (Air Conditioning) Yang Menggunakan Freon R-134 A Berdasarkan Pada Variasi Putaran Kipas Pendingin. Bina Teknika, 11(2), 124-130.

Susilo, B., Hermanto, M. B., Mujahidin, A., Djoyowasito, G., \& Damayanti, R. (2020). Performance of Drying Machine with Air Dehumidifying Process for Sweet Corn Seed (Zea mays saccharata). IOP Conference Series: Earth and Environmental Science, 515(1), 12008.

Świeca, M., Kordowska-Wiater, M., Pytka, M., Gawlik-Dziki, U., Bochnak, J., Złotek, U., \& Baraniak, B. (2018). Lactobacillus plantarum 299V improves the microbiological quality of legume sprouts and effectively survives in these carriers during cold storage and in vitro digestion. PLoS One, 13(11), e0207793. 